\title{
Global Dysfunction Determinants of Regional Capital Markets (Russia and Iraq as Case Studies)
}

\author{
Elena V. Ogurtsova \\ Department of Economics \\ Saratov State University \\ Saratov, Russia \\ tirolmen@yandex.ru
}

\author{
Imad Yasir Hussein \\ Department of Economics \\ Saratov State University \\ Saratov, Russia \\ yaseeremad82@gmail.com
}

\begin{abstract}
The article analyzes the impact of globalization and internationalization of the world economy on capital markets functioning in macro-regions - Russia and Iraq and development of these markets dysfunction. The research is based on the methodology of a systematic approach, which allows considering territorial-industrial complexes, economic sectors, regions as parts of the larger system - a national economy of the world economy, a capital market as an integral part of a national economy system. The study is aimed at identifying exogenous factors of unstable development for integral multilevel spatialterritorial economic systems of a certain branch specialization holding a peripheral position in the world-system space organization. The article draws attention to the formation of capital markets dysfunction of these macro-regions - the most important element of their self-development mechanism. The forms of influence of global determinants on the capital markets functioning which were established in the course of the study enable to determine the limits of sustainable development of territorial economic systems and the need to improve state financial and investment policy aimed at reducing destructive effects of the influence.
\end{abstract}

Keywords- capital market, economical disfunction, regional development, regional policy, economic space, macro-region, globalisation

\section{INTRODUCTION}

The effective capital market functioning is one of the key problems of sustainable development in integral multi-level spatial-territorial economic systems of a certain branch specialization holding a peripheral position in the worldsystem space organization, the so-called periphery. The efficiency of investment activity, a high speed of capital formation, productivity of savings are major provisions of sustainable development of an economic system, both at macro- and meso- levels, which reflect the mode of the capital market functioning. In the framework of the regional selfdevelopment concept [1], [2], [3] the long-term sustainability of regional development is determined equally by internal self-sufficiency, ensuring long-term sustainability of regional development due to the existing economic potential, as well as favorable external conditions, effective institutions forming and reproducing the foreign macro-economic environment with the effective use of territorial opportunities, economic and financial resources.
The state of capital markets in modern conditions is defined not so much by endogenous factors as by exogenous determinants: globalization of the world economy, the state of the international capital market, the geopolitical situation.

Economy globalization manifests itself as liberalization of foreign economic relations; scaling up and accelerating the capital flow; unhindered circulation of financial information; advanced development of international trade and investment in comparison to production. Development of the digital economy, information and communication technologies has even more strengthened these processes [4]. High involvement of the economic system in global processes increases competitiveness of the economy, GDP growth rates, standards and quality of life.

At the same time, the influence of globalization on the capital markets functioning in the regions of the periphery is not so clear: there is an increase in the imbalance of the sectoral structure typical for the periphery regions; a decrease in the intensity of the capital formation process and the growing instability of these regions' development. The balance of payments of the Russian Federation demonstrates deterioration in the international balance of investment income, the negative international balance of investment income amounted to a total of $\$ 429.0$ billion for 10 years from 2005 to 2015 [5]. This fact shows that globalization in the absence of domestic policy on the capital flows regulation leads to the serious dysfunction of the capital market, its fallout from the process of the capital formation in the regional economic system and conversion to a tool increasing the imported foreign capital profitability. As a result, it threatens stability of the territorial economic systems development.

The need to overcome the destructive impact of globalization on regional development, to improve sustainable functioning of the periphery regions makes the study on the formation of capital market dysfunction relevant; involves the analysis of the globalization impact on their functioning and recommendations for incensement in the efficiency of the state financial and investment policy.

The goal of the study is to define global determinants of the capital market dysfunction of integral multi-level spatial and territorial economic systems holding a peripheral position in the world-system space organization; to establish forms of 
influence of globalization on the capital markets functioning in Russia and Iraq.

This goal is achieved through justification of scientific hypotheses, defining determinism of the capital markets dysfunctions in the periphery regions by the growth in their institutional, economic and trade openness, globalization and internationalization; establishing relevant indicators of the exogenous factors influence on the capital market functioning; empirical data collection to study the forms of globalization influence on formation of capital markets dysfunctions in Russia and Iraq; the definition of opportunities within the framework of the state economic policy to reduce the destructive effects made by the global determinants of the capital markets dysfunction.

\section{MATERIALS AND METHODS}

Statistical data of the Russian Federal State Statistics Service for 2005-2016; UNCTAD statistical databases; statistical data of the Ministry of Planning of the Republic of Iraq were used to identify global determinants of the capital markets dysfunctions in the integral multilevel spatialterritorial economic systems holding a peripheral position in the world-system space organization - regions of the periphery.

Capital markets of Russia and Iraq, featured with the dysfunction of funds spatial distribution (spatial deformation), underdevelopment and low efficient functioning, were chosen as the objects of the study. These markets characterized by a poorly diversified sectoral structure of the stock market (more than $2 / 3$ of capitalization falls on oil, gas and metallurgy industries); a low activity of individual and institutional investors; a high concentrated banking sector; centralized financial flows in banks with state participation and a low competition.

General principles of the system approach formed the basis of this study. The principles of determinism, comparative, structural and functional analysis were used to examine the conditions for the capital markets functioning in the periphery regions, to assess the impact made by such exogenous factor as globalization on the formation of these markets dysfunctions. Structural and functional analysis is used as a specific principle in the system research of processes and phenomena interpreted as a structurally dissected integrity which structural elements have its own specific functional purpose.

The implementation of a systematic approach to the study of the global determinants of the capital market in the periphery regions allowed outlining functions and the target orientation of its development, while the function is considered to be the main system-forming factor. Qualitative assessment of the capital market in the periphery region is given in the framework of the functional analysis from the perspective of how the implementation of its functions is complete if there are certain changes in the external environment.
Scientific hypothesis, which measures the determinacy of the capital markets dysfunctions in the periphery regions by the growth in their institutional, economic and trade openness, globalization and internationalization, is based on the dysfunction theory of economic systems and institutions [6], [7], [8]. According to this theory, a dysfunction of a system, a subsystem, an institution is a disruption, malfunction of mainly qualitative nature, in other words it is inability to realize their function (a set of functions) or its insufficient realization. In reality each economic system, subsystem, institute are characterized by a certain value of dysfunctionality. Any system performs a certain set of functions identified by the economic science, but in the particular institutional and economic environment the parameters of its activity inevitably deviate from theoretical ones, and that what the dysfunctionality is.

When studying the capital market functioning in the periphery region, it is expected that the object of the analysis acts expediently, in the "interests" of the territorial economic system: ensures its integrity preservation and sustainable development.

The capital market dysfunction arising in the periphery regions under the influence of global determinants becomes the reason for reduction in the synergetic (allokative and adaptive) efficiency of the regional socio-economic system. The stability of its development is undermined. There is a need to compensate for the dysfunctionality of the capital market by effective financial and investment state policy implemented at all levels of the spatial and territorial economic system. In order to ensure the structural integrity and dynamic coherence of management levels, it is important for each of them to meet a new stage of development stimulated by changed economic conditions, the growing scale of economic globalization and internationalization.

In accordance with the defined approaches to the research, new indicators of global changes were established; the directions and forms of the influence on the capital markets functioning in the analyzed regions of the periphery were identified. Based on statistical data on the volume of financial flows, their direction and usage in the study, the efficiency of the capital market is determined, these parameters are used as criteria for assessing its dysfunctions.

The forms of influence of global changes in the world economy on the capital markets functioning in the regions of the periphery, defined as a result of the carried-out analysis, enable to formulate directions of state economic policy on restriction of global determinants of the capital market dysfunction in these regions and improvement of its functioning efficiency.

\section{RESULTS AND DISCUSSION}

The study revealed the following global determinants of the capital market dysfunction in the periphery regions:

- international conjuncture (environment) - significant economical involvement of the periphery regions in international economic relations, dependence of these regions' economy on foreign markets. The share of 
export in gross domestic product (GDP) (export quota) is an indicator which characterizes involvement of a state's economy in international economic relations (and therefore its dependence on the world market). Currently the export quota of all states amounts to $30 \%$ of the global GDP. Export quotas of both Russia and Iraq have decreased in recent years, however they meet the international standards being equal to $26.2 \%$ [9] and $27.87 \%$ [10] respectively;

- accelerated internationalization and transnationalization of financial markets. The global flow of foreign direct investment (FDI) has increased by $38 \%$ within the period 2014-2017: in 2014 its volume was $\$ 1.3$ trln., in $2017-\$ 1.8$ trln. [11]. Last decade the growth rate of foreign direct investment outpaced the growth of the world gross product more than 5 times. FDI inflows to Russia increased from \$ 12 bln. in 2015 to \$ 38 bln. in 2016 [11];

- financial globalization: conversion of the United States dollar into the world currency; "linking" of the national currency to the US dollar exchange rate, less often to the EURO; formation of foreign exchange reserves through accumulation of currencies of the economically developed states; making international trade payments in dollars and EUROS; foreign exchange market (purchase and sale of currency) is the main element of the international capital market;

- strengthening influence of geopolitics (foreign economic and financial policy), pursued by developed states, on the economy of the periphery regions.

As a result of combining qualitative and quantitative methods of analyzing the capital markets functioning in the periphery regions in conditions of dominating exogenous factors the forms of influence of the world economy globalization and internationalization on the formation of these markets' dysfunction was established.

I The $1^{\text {st }}$ form of influence globalization has on the formation of the capital market dysfunction in the periphery regions is an enhancing role of international organizations and financial institutions; a limitation of the state regulatory capacity. The increasing institutional and trade-economic openness of the markets in the periphery regions has changed the ratio of endogenous and exogenous factors of their development. If earlier the decisive role was played by endogenous (internal) factors, nowadays it belongs to the world economy processes. The growing influence of external factors has significantly limited the capabilities of national governance institutions in regulating the functioning of the territorial economic system; the state monetary and fiscal policy is becoming less effective.

The activity of international organizations and institutions restrict regulatory capabilities of a state. They are regulated by special international institutions - the IMF, IBRD, WTO, UNCTAD and others. Internationalization of capital markets has contributed to the common international standards formation. National legislation should be adapted to the requirements of international trade and investment organizations.

Strengthening of international interstate regulation institutions has a negative impact on economic systems. Due to liberalization of foreign economic activity the developed states, their transnational corporations (TNC) and banks (TNB) have gained competitive advantages compared to less developed countries, the disparity effect in the capital market development of the periphery regions is observed. For example TNBs are designing an international banking service infrastructure that excludes other banks from the capital market and improve their competitiveness. TNBs, pursuing business objectives, set out favorable conditions for gaining access to foreign markets, creating entry barriers for competitors, strengthening their own competitive positions.

The TNC activity is poorly controlled, so it might be accompanied by imbalances in the territorial and sectoral development of the economic system. It is responsibility of a government to take this moment into account and to avoid structural imbalances, but the state capabilities are often limited. For instance, individual states cannot effectively influence on Citigroup, General Electric Capital, American International Group, Deutsche Bank. A number of international financial institutions, such as the European Bank for Reconstruction and Development, the Overseas Private Investment Corporation (OPIC), the Multilateral Investment Guarantee Agency (MIGA), also dictate their terms. Under the influence of these international financial organizations liberalization of the capital market in the periphery regions is taking place.

II The $2^{\text {nd }}$ form of influence globalization has on the formation of the capital market dysfunction in the periphery regions - the abroad flight of domestic financial resources. Among the reasons of the "capital flight" are: high business risks (national currency volatility, high inflation rate, private property nationalization risks); enterprise assets transfer to the personal property of its owners and managers; the desire to purchase property abroad; direct and portfolio investments into the national economy which are masked as foreign.

Negative impacts (direct and indirect) of the capital outflow is manifested in declining investment potential of the economic system and the reduction in domestic investments; increasing volatility of the capital market and the national currency; deterioration of the balance of payments; reduction of tax revenues to the state budget and the budgets of the Russian Federation constituent entities; limitation of capabilities in realization of social programs. All this eventually has a negative influence on competitiveness of the economic system.

The capital outflow has increased in Russia since the beginning of the global financial crisis in 2008. Net capital outflow amounted to $\$ 133.6$ billion in 2008 alone. It was particularly significant in $2011-\$ 81.4$ billion. In total, $\$ 678.2$ billion was withdrawn from Russia within the period from 2008 to 2017, while the inflow was about $\$ 350$ billion [12]. The increase in the external debt is explained by the fact that the cheaper credit resources could be borrowed from the external market. Russia entered a crisis with a large foreign 
economic debt, it was mainly corporate debt of enterprises and organizations ( $\$ 480$ billion at the beginning of 2009). Companies continued to attract more foreign funds to overcome the crisis. As a result, the debt amounted to $\$ 539$ billion at the end of 2011 and $\$ 636$ billion at the end of 2012, 2013 - \$ 729 billion, 2014 - the debt was \$ 599.9 billion, 2015 - \$ 519 billion, 2016 - 514,1, and in 2017 - \$536,7 billion [13]. The growth of the foreign trade debt reduces the growth of budget revenues, credit resources, enterprises' own funds, which could be used for socio-economic development.

There is also a phenomenon of the capital outflow in Iraq due to the fact that foreign banks are more reliable than national ones, as well as due to the economic and political instability of the state, the lack of attractive opportunities and advantages, unlike other countries. "The external debt of Iraq is estimated at $\$ 125$ billion and represents a great financial burden for the economy being undoubtedly a negative factor. In this regard creation of a favorable investment climate would greatly contribute to the reduction of the Iraqi debt" [14].

III The $3^{\text {rd }}$ form of influence globalization has on the formation of the capital market dysfunction in the periphery regions, namely Russia and Iraq - the structural transformation of the national capital market.

The legislation either in Russia and Iraq provides the following forms of foreign investment: establishment of joint ventures with the share participation of foreign investors; establishment of enterprises with $100 \%$ ownership of foreign investors; acquisition of shares, bonds of national enterprises by foreign investors; acquisition and long-term lease of land; provision of various loans, property and property rights. Foreign investments increase the investment potential of the territorial economic system, investment demand, employment and incomes of the population, budget revenues, technical and technological level of production, expand export potential.

Among existing forms of ownership in Russia a significant share falls on foreign and mixed (with the foreign capital participation) property. In 2016 its share was $16.7 \%$ of the fixed capital of industry [15]. Preference is given to attracting foreign direct investments (FDI) into the real economy. According to statistics, the largest volume of FDI was $\$ 74783$ million in 2008, then it began steadily decline. In 2014 the volume of direct investments amounted to 22031 million and in 2015 it dropped sharply to 6478 million dollars [15]. Their current low share in the GDP and the gross fixed capital formation in Russia does not meet modern needs of the economy. The same is true for the situation with FDI in the economy of Iraq (Table 1).

The Table 1 shows dynamics of foreign direct investment in the economy of Iraq for ten years from 2005 to 2015 [16].
TABLE I. DYNAMICS OF FOREIGN DIRECT INVESTMENT (FDI) INFLOW IN THE ECONOMY OF IRAQ FROM 2005 TO 2015 (MLN. US DOLL.)

\begin{tabular}{|c|c|}
\hline Years & Foreign Direct Investment Inflow \\
\hline 2005 & 0,515 \\
\hline 2006 & 0,383 \\
\hline 2007 & 0,972 \\
\hline 2008 & 1,856 \\
\hline 2009 & 1,598 \\
\hline 2010 & 1,396 \\
\hline 2011 & 1,882 \\
\hline 2012 & 3,4 \\
\hline 2013 & 5,131 \\
\hline 2014 & 4,782 \\
\hline 2015 & 3,468 \\
\hline
\end{tabular}

Statistics demonstrate insignificant volumes of FDI and a high instability of their dynamics.

The structure of foreign investments attracted to Russia is deformed. In the structure of the foreign capital the main share falls on short-term investments: operations with foreign currency, insurance payments and payments in foreign currency, short-term loans and credits, bank deposits, investments in short-term securities. Long-term investments investments in the real sector of the economy, long-term securities, long-term loans and credits have a smaller share. This increases the external debt of the state and the amount of annual payments associated with its repayment.

It should be noted that there is extremely uneven distribution of FDI among the Russian and Iraqi regions. The most attractive regions in Russia are the regions of raw materials, Moscow and Moscow oblast, as well as some constituent entities of the Russian Federation, which are close to them. The main recipients of foreign investments in Iraq are oil-producing regions.

Generally, the potential of Russia and Iraq in the sphere of attracting foreign direct investments remains underdeveloped. Their current scale does not allow intensification of domestic investment processes. In terms of the FDI share in GDP, the studied states lag far behind a lot of developing countries, the world average values.

The analysis of influence the exogenous factors have on the capital market functioning in the periphery regions made it possible to identify changes in its functioning, to define dysfunctions and their consequences for regional development. The dysfunctionality of the capital market in the regions of the periphery is manifested in the following:

- the spatial deformation of the capital market (the dysfunction of fibabcial spatial distribution);

- the redistributive dysfunction of the capital market (i.e. financial resources are concentrated in one segment of 
the economy, while other industries are experiencing a lack of capital);

- the capital formation dysfunction (weak accumulation of free funds of the population and business, wasteful use of capital, increasing capital outflow).

The most serious consequences for sustainable development of the economic system of the periphery region is a redistributive dysfunction of the capital market, it creates a structural imbalance of the regional economy. Russian and Iraqi economies are characterized by excessive development of the extractive industry, in particular oil production.

The sectoral structure of the economy needs to be optimized. There is a trend of selective foreign investment in the most attractive sectors both in Russia and Iraq. Therefore, major direct foreign investments go to primary sectors and to the industries of production infrastructure. As a result, the share in the GDP of the fuel and energy sector, primary processing of raw materials is growing, when the share of agriculture, construction, machine-building industries and industries producing consumer goods has significantly decreased. The deformation of the economy's sectoral structure continues to grow.

However, the degree of the capital market dysfunctionality is an indicator of how the state's actions, its financial and investment policy is effective.

In 2003, The Coalition Provisional Authority of Iraq issued Law No. 39 on foreign investment. The provisions of the Law include [17]: securing real guarantees for foreign investors in the form of protection of their rights and capital in Iraq; the possibility of export of accumulated profits outside the country; insurance and protection of foreign business against unforeseen circumstances; non-interference in pricing of investors' products; removal of control over financial statements of companies; reduction of tax rates for foreign companies (not more than $15 \%$ instead of the former $45 \%$ ). Guarantees, preferences and benefits had stimulated FDI into the country, but political instability and hostilities prevented full realization of their potential.

In 2006 Iraq adopted the Investment Law, which provided for the establishment of the "National Investment Commission". It has stimulated a significant inflow of foreign investments in the Iraqi economy, conclusion of contracts with major oil and gas TNCs: Exxon Mobile, Total, Eni, China National Petroleum Corporation, the Russian JSC "Gazpromneft", "Lukoil" and others.

One of the most important conditions for the effective functioning of the capital market in the periphery regions is formation of the resource base for the financial system of a region and a favorable investment climate. Investors consider taxes, deficiencies in the legal regulation, bureaucracy and corruption to be the main obstacles to the expansion of investment volumes. Some of them depend on actions of the authorities, others are objective (for example, geographical location, external market conditions). The main influence on the investment climate is exerted by the state through solving such problems as political and economic instability; ensuring property rights; taxation; conditions for the capital market functioning.

\section{CONCLUSION}

In modern conditions successful development of a territorial economic system is impossible without participation in international financial and economic processes.

In the context of globalization, international organizations and institutions, TNCs have an increasing impact on the national economy: the capital movement; investment processes; specification of property rights; reformation of the economy and its individual sectors; effectiveness of government regulation and management; introduction of new methods and forms of management; business lending. The results of this impact are ambiguous and contradictory. In the conditions of the limited regulatory capacity of the state they make a territorial economic system of the periphery regions more unstable, susceptible to macroeconomic shocks. There is a need to develop effective state measures for the use of foreign economic relations in order to optimize the sectoral structure of the economy of the region, to increase its capital availability, and, as a consequence, the sustainability of development.

The global financial crisis has shown the need to increase the resource base of the financial system of the region. The current practice of financing economic development through cheap external borrowing has demonstrated its limitations. The new development model should be based on its own competitive banking and financial system.

\section{References}

[1] Tatarkin, A. I. Samorazvivayushchiesya sotsialnoekonomicheskie sistemy: teoriya, metodologiya, prognoznye otsenki: v 2 t. [Self-developing socio-economic systems: theory, methodology, projections: in 2 vol.]. Ros. akad. nauk, Ural. Otd-nie [Ural Branch of RAS]. In: A. I. Tatarkin (Ed.). Moscow: Ekaterinburg: Economika Publ., UrO RAN Publ. T.1: Teoriya i metodologiya formirovaniya samorazvivayushchikhsya sotsialno-ekonomicheskikh system [Vol.1: Theory and methodology of formation of selfdeveloping socio-economic systems], 308 p. (in Russian)

[2] Doroshenko S.V. Self-development of the region in the region in the context of economic evolution. Zhurnal ekonomicheskoi teorii [Russian Journal of Economic Theory], 2009, no 3, pp. 21-30. (in Russian)

[3] Fedolyak V.S. Regions Self-development as Way of Realization of Economic Potential. Izv. Saratov Univ. (N.S.), Ser. Economics, Management, Law, 2017, vol. 17, iss. 4, pp. 428-433. (in Russian)

[4] Held D., Goldblatt D., McGrew A., Perratan J. Global transformations: Politics, economics and culture. Cambridge. Oxford: Polity Press, 2000. 515 p. (Russ. Ed.:

(Russ. ed. : Held D., Goldblatt D., McGrew A., Perratan J. Global'nye transformatsii: politika, economika, kultura. Moscow, Pracsis, 2004. 576 p.). 
[5] The Russian Federal Service of State Statistics [Rosstat]. URL: http://www.gks.ru/free_doc/doc_2016/fin16.pdf

[6] Sukharev, O.S. Teoriya disfunkcii e'konomicheskix sistem $\mathrm{i}$ institutov. [The theory of dysfunction of economic systems and institutions]. Moscow: LENAND, 2014. 144 p. (in Russian)

[7] Polterovich V.M. Institucional’ny`e lovushki i e`konomicheskie reformy` [Institutional traps and economic reforms]. E`konomika i matematicheskie metody'. [Economics and mathematical methods], 1999. Vol. 35. id.2. pp. 1 - 37. (in Russian)

[8] Frolov D.P. Metaforizm institucionalizma: fizikalizm, biologizm [Metaforizm institucionalizma: fizikalizm, biologizm]. TERRA ECONOMICUS. 2013. Vol. 11. No 3. pp. 34-51. (in Russian)

[9] The Russian Federal Service of State Statistics [Rosstat]. URL: http://www.gks.ru/free_doc/doc_2017/year/year17.pdf

[10] UNCTADstat. Site. Database. National accounts. Gross domestic product: GDP by type of expenditure, VA by kind of economic activity, total and shares, annual, 1970-2016. Available

at: http://unctadstat.unctad.org/wds/TableViewer/tableView.aspx [11] Doklad o mirovy`x investiciyax za 2017 god. Investicii i cifrovaya e`konomika. Osnovny`e tendencii i obshhij obzor. (The world investment report for 2017. Investment and the digital economy. Main trends and General overview.) Available at: http://unctad.org/en/PublicationsLibrary/wir2017_Overview _ u.pdf (in Russian)

[12] Central'ny`j Bank RF. Makroe`konomicheskaya statistika. Statistika vneshnego sektora. Chisty`j vvoz/vy`voz kapitala chastny`m sektorom v 1994-2017 gg. The Central Bank of the Russian Federation. Macroeconomic statistics. External sector statistics. Net import / export of capital by the private sector in 1994-2017. Available at: http://www.cbr.ru/statistics/?PrtId=svs (in Russian)

[13] Central`ny`j Bank RF. Makroe`konomicheskaya statistika. Statistika vneshnego sektora. Vneshnij dolg Rossijskoj Federacii. The Central Bank of the Russian Federation. Macroeconomic statistics. External sector statistics. Foreign debt of the Russian Federation. Available at: http://www.cbr.ru/statistics/?PrtID=svs (in Russian)

[14] Anees Zyara Muhi Al-Fahad. Pryamy`e inostranny`e investicii v Irake v svete Zakona ob investiciyax № 13 za 2006 god. [Foreign direct investment in Iraq in the light of investment Act No. 13 of 2006]. [Actual problems of Humanities and natural Sciences]. 2017. No 6-2. pp.47-53 Available at: https://publikacia.net/archive/2017/6/2/10 (in Russian)

[15] The Russian Federal Service of State Statistics [Rosstat]. URL: http://www.gks.ru/free doc/doc_2017/year/year17.pdf [16] Statistical Report of the Central Bureau of Statistics and Information Technologies 2010-2011. Ministry of Planning. Iraq. Available at: https://mop.gov.iq/en/page/view/details?id=83(in Arabian).

[17] Hakem Mohsen Mohammed. Analysis of the investment environment for foreign financial investment in Iraq. Available http://www.ahlulbaitonline.com/karbala/New/html/research/re search.php?ID=76 (in Arabian). 